\title{
Mitral valve prolapse: a source of arrhythmias?
}

\author{
E. E. van der Wall • M. J. Schalij
}

Received: 10 November 2009/Accepted: 10 November 2009/Published online: 24 November 2009

(C) The Author(s) 2009. This article is published with open access at Springerlink.com

Cardiac arrhythmias are frequently detected in patients with mitral valve prolapse (MVP) The proper mechanisms causing ventricular arrhythmias in patients with MVP have not been fully investigated. In the current issue of the International Journal of Cardiovascular Imaging, Turker et al. [1] evaluated the clinical, echocardiographic and heart rate variability (HRV) parameters, and plasma concentrations of electrolytes and inflammatory markers in predicting ventricular arrhythmias in 58 consecutive patients with MVP. Ventricular arrhythmias were defined as the occurrence of ventricular premature contractions (VPCs), VPC couplets, and ventricular tachycardias documented by Holter analysis, continuous monitoring or by electrocardiography. Twenty patients (34\%) showed ventricular arrhythmias, and $38(66 \%)$ patients did not have ventricular arrhythmias. Seventeen patients had VPC, 2 patients had VPC couplets and one patient had ventricular tachycardia. Univariable predictors of ventricular arrhythmias included echocardiography-determined isovolumetric relaxation time and the presence of moderate to severe mitral regurgitation. Interestingly, multivariable logistic regression analysis showed that

Editorial comment on the article of Turker et al. (doi:10.1007/s10554-009-9514-6).

E. E. van der Wall $(\bowtie) \cdot$ M. J. Schalij

Leiden University Medical Center, Leiden,

The Netherlands

e-mail: E.E.van_der_Wall@lumc.nl occurrence of moderate to severe mitral regurgitation was the only independent predictor of ventricular arrhythmias.

Several recent studies did already address the relation between cardiac arrhythmias and the presence of MVP. Chen et al. [2] showed that improper autonomic tone is to be considered the etiology of arrhythmias in conjunction with MVP. Heart rate turbulence (HRT) and HRV are methods assessed for autonomic dysfunction. The authors studied the relationship of HRT, HRV and the number of ventricular premature beats in patients with MVP and non-significant mitral regurgitation. No significant correlation was found between the number of VPCs and HRT/HRV parameters. MarkiewiczŁoskot et al. [3] studied electrocardiographic abnormalities in ten young athletes with MVP. Abnormal ECG repolarization was found in seven athletes. Young athletes with MVP are therefore often predisposed to electrocardiographic abnormalities of ventricular repolarization. Cetinkaya et al. [4] evaluated the risk of vasovagal syncope and cardiac arrhythmias in 37 children with MVP. Arrhythmias and the risk of vasovagal syncope, indicated by a positive tilt test, were found to be increased in children with MVP.

Similar to echocardiography [5-13], cardiovascular magnetic resonance (CMR) imaging can identify MVP by similar anatomic and functional criteria [13-30]. In addition, CMR allows tissue characterization in various cardiac diseases using hyperenhancement 
techniques [31-38]. In this way, CMR can identify myocardial fibrosis involving the papillary muscle in MVP patients. Delayed contrast enhancement (DCE) of papillary muscles is often present in a subgroup of patients with complex ventricular arrhythmias [39]. This tissue hyperenhancement is indicative of fibrosis which may act as a focus for arrhythmias. Kwon et al. [40, 41] using delayed contrast enhancement CMR, showed a clear association of myocardial fibrosis, electrocardiography and ventricular tachyarrhythmia in hypertrophic cardiomyopathy (HCM). HCM subjects with ventricular tachycardias showed a higher percentage of myocardial scarring on DCE-CMR. As a consequence, the presence of fibrotic papillary muscles in patients with MVP might give rise to both cardiac arrhythmias and mitral regurgitation. In addition to echocardiography and CMR, multislice computed tomography (MSCT) has recently been shown to evaluate the functional status of the mitral valve in patients with MVP [42-45]. MSCT may therefore have a major role in preoperative assessment of the mitral valve apparatus before mitral valve surgery.

To summarize, nowadays the diagnosis of MVP can be made by several imaging techniques. Apart from echocardiography, CMR and MSCT are capable of accurately delineating the structure and function of the mitral valve. Next, there is a clear association between the level of incompetence of the mitral valve and the presence of cardiac arrhythmias, in particular in case of MVP. These findings have been proven both by echocardiography and DCE-CMR. The study by Turker et al. [1], using echocardiography, add to these results by showing that the occurrence of moderate to severe mitral regurgitation was the only independent predictor of ventricular arrhythmias in patients with MVP.

Open Access This article is distributed under the terms of the Creative Commons Attribution Noncommercial License which permits any noncommercial use, distribution, and reproduction in any medium, provided the original author(s) and source are credited.

\section{References}

1. Turker Y, Ozaydin M, Acar G et al. (2009) Predictors of ventricular arrhythmias in patients with mitral valve prolapse. Int J Cardiovasc Imaging. doi:10.1007/s10554-0099514-6

2. Chen HY (2009) Relationship of heart rate turbulence, heart rate variability and the number of ventricular premature beats in patients with mitral valve prolapse and non-significant regurgitation. Int J Cardiol 135:269271

3. Markiewicz-Łoskot G, Łoskot M, Moric-Janiszewska E et al (2009) Electrocardiographic abnormalities in young athletes with mitral valve prolapse. Clin Cardiol 32: E36-39

4. Cetinkaya M, Semizel E, Bostan O, Cil E (2008) Risk of vasovagal syncope and cardiac arrhythmias in children with mitral valve prolapse. Acta Cardiol 63:395-398

5. Nevo ST, van Stralen M, Vossepoel AM et al (2007) Automated tracking of the mitral valve annulus motion in apical echocardiographic images using multidimensional dynamic programming. Ultrasound Med Biol 33:13891399

6. van Stralen M, Leung KY, Voormolen MM et al (2008) Time continuous detection of the left ventricular long axis and the mitral valve plane in 3-D echocardiography. Ultrasound Med Biol 34:196-207

7. Leung KY, van Stralen M, Nemes A et al (2008) Sparse registration for three-dimensional stress echocardiography. IEEE Trans Med Imaging 27:1568-1579

8. Schuijf JD, Bax JJ, van der Wall EE (2007) Anatomical and functional imaging techniques: basically similar or fundamentally different? Neth Heart J 15:43-44

9. Ypenburg C, van der Wall EE, Schalij MJ, Bax JJ (2008) Imaging in cardiac resynchronisation therapy. Neth Heart J 16:S36-S40

10. Kamp O (2008) History of echocardiography in the Netherlands: 30 years of education and clinical applications. Neth Heart J 16:16-20

11. Cramer MM, De Boeck BW (2007) Three-dimensional echocardiography and left bundle branch block: prime time in cardiology. Neth Heart J 15:87-88

12. Kleijn SA, Kamp O (2009) Clinical application of threedimensional echocardiography: past, present and future. Neth Heart J 17:18-24

13. Braun S, van der Wall EE, Emanuelsson H, Kobrin I (1996) Effects of a new calcium antagonist, mibefradil (Ro 40-5967), on silent ischemia in patients with stable chronic angina pectoris: a multicenter placebo-controlled study. The Mibefradil International Study Group. J Am Coll Cardiol 27:317-322

14. van der Wall EE, Vliegen HW, de Roos A, Bruschke AV (1995) Magnetic resonance imaging in coronary artery disease. Circulation 92:2723-2739

15. Bavelaar-Croon CD, Kayser HW, van der Wall EE et al (2000) Left ventricular function: correlation of quantitative gated SPECT and MR imaging over a wide range of values. Radiology 217:572-575

16. Bax JJ, Lamb H, Dibbets P et al (2000) Comparison of gated single-photon emission computed tomography with magnetic resonance imaging for evaluation of left ventricular function in ischemic cardiomyopathy. Am J Cardiol 86:1299-1305

17. Pluim BM, Beyerbacht HP, Chin JC et al (1997) Comparison of echocardiography with magnetic resonance imaging in the assessment of the athlete's heart. Eur Heart J 18:1505-1513

18. van der Wall EE, den Hollander W, Heidendal GA, Westera G, Majid PA, Roos JP (1981) Dynamic 
myocardial scintigraphy with $123 \mathrm{I}$-labeled free fatty acids in patients with myocardial infarction. Eur J Nucl Med 6: 383-389

19. Holman ER, Buller VG, de Roos A et al (1997) Detection and quantification of dysfunctional myocardium by magnetic resonance imaging. A new three-dimensional method for quantitative wall-thickening analysis. Circulation 95:924-931

20. van Rugge FP, Holman ER, van der Wall EE et al (1993) Quantitation of global and regional left ventricular function by cine magnetic resonance imaging during dobutamine stress in normal human subjects. Eur Heart J 14:456-463

21. Pluim BM, Lamb HJ, Kayser HW, Leujes F et al (1998) Functional and metabolic evaluation of the athlete's heart by magnetic resonance imaging and dobutamine stress magnetic resonance spectroscopy. Circulation 97:666-672

22. van Rugge FP, van der Wall EE, Spanjersberg SJ et al (1994) Magnetic resonance imaging during dobutamine stress for detection and localization of coronary artery disease. Quantitative wall motion analysis using a modification of the centerline method. Circulation 90:127-138

23. Nemes A, Geleijnse ML, van Geuns RJ et al (2008) Dobutamine stress MRI versus threedimensional contrast echocardiography: it's all black and white. Neth Heart J $16: 217-218$

24. Vliegen HW, Doornbos J, de Roos A, Jukema JW, Bekedam MA, van der Wall EE (1997) Value of fast gradient echo magnetic resonance angiography as an adjunct to coronary arteriography in detecting and confirming the course of clinically significant coronary artery anomalies. Am J Cardiol 79:773-776

25. van der Wall EE, Heidendal GA, den Hollander W, Westera G, Roos JP (1980) I-123 labeled hexadecenoic acid in comparison with Thallium-201 for myocardial imaging in coronary heart disease. A preliminary study. Eur J Nucl Med 5:401-405

26. Hoogendoorn LI, Pattynama PM, Buis B, van der Geest RJ, van der Wall EE, de Roos A (1995) Noninvasive evaluation of aortocoronary bypass grafts with magnetic resonance flow mapping. Am J Cardiol 75:845-848

27. Langerak SE, Vliegen HW, de Roos A et al (2002) Detection of vein graft disease using high-resolution magnetic resonance angiography. Circulation 105:328-333

28. Tulevski II, Hirsch A, Sanson BJ et al (2001) Increased brain natriuretic peptide as a marker for right ventricular dysfunction in acute pulmonary embolism. Thromb Haemost 86:1193-1196

29. van der Geest RJ, de Roos A, van der Wall EE, Reiber JH (1997) Quantitative analysis of cardiovascular MR images. Int J Card Imaging 13:247-258

30. van der Geest RJ, Niezen RA, van der Wall EE, de Roos A, Reiber JH (1998) Automated measurement of volume flow in the ascending aorta using MR velocity maps: evaluation of inter- and intraobserver variability in healthy volunteers. J Comput Assist Tomogr 22:904-911

31. de Roos A, Matheijssen NA, Doornbos J et al (1990) Myocardial infarct size after reperfusion therapy: assessment with Gd-DTPA-enhanced MR imaging. Radiology 176:517-521
32. de Roos A, Matheijssen NA, Doornbos J, van Dijkman PR, van Rugge PR, van der Wall EE (1991) Myocardial infarct sizing and assessment of reperfusion by magnetic resonance imaging: a review. Int J Card Imaging 7:133-138

33. van Rugge FP, Boreel JJ, van der Wall EE et al (1991) Cardiac first-pass and myocardial perfusion in normal subjects assessed by sub-second Gd-DTPA enhanced MR imaging. J Comput Assist Tomogr 15:959-965

34. van Rugge FP, van der Wall EE, van Dijkman PR, Louwerenburg HW, de Roos A, Bruschke AV (1992) Usefulness of ultrafast magnetic resonance imaging in healed myocardial infarction. Am J Cardiol 70:1233-1237

35. Holman ER, van Jonbergen HP, van Dijkman PR, van der Laarse A, de Roos A, van der Wall EE (1993) Comparison of magnetic resonance imaging studies with enzymatic indexes of myocardial necrosis for quantification of myocardial infarct size. Am J Cardiol 71:1036-1040

36. Holman ER, van Rossum AC, Doesburg T, van der Wall EE, de Roos A, Visser CA (1996) Assessment of acute myocardial infarction in man with magnetic resonance imaging and the use of a new paramagnetic contrast agent gadolinium-BOPTA. Magn Reson Imaging 14:21-29

37. Nijveldt R, Beek AM, Hirsch A et al (2008) 'No-reflow' after acute myocardial infarction: direct visualisation of microvascular obstruction by gadolinium-enhanced CMR. Neth Heart J 16:179-181

38. Han Y, Peters DC, Salton CJ et al (2008) Cardiovascular magnetic resonance characterization of mitral valve prolapse. JACC Cardiovasc Imaging 1:294-303

39. Kwon DH, Setser RM, Popović ZB et al (2008) Association of myocardial fibrosis, electrocardiography and ventricular tachyarrhythmia in hypertrophic cardiomyopathy: a delayed contrast enhanced MRI study. Int J Cardiovasc Imaging 24:617-625

40. Kwon DH, Smedira NG, Rodriguez ER et al (2009) Cardiac magnetic resonance detection of myocardial scarring in hypertrophic cardiomyopathy: correlation with histopathology and prevalence of ventricular tachycardia. J Am Coll Cardiol 54:242-249

41. Gerber TC, Kuzo RS, Safford RE (2005) Posterior mitral valve leaflet prolapse diagnosed with multislice spiral computed tomography. Heart 91:130

42. Wong TW, De Larrazabal C, Boey HK, Lim MC (2007) Flail P2 cusp of posterior mitral valve leaflet demonstrated on multi-slice computed tomography. Int $\mathrm{J}$ Cardiol 115:e31-32

43. Bleeker GB, Holman ER, Steendijk P et al (2006) Cardiac resynchronization therapy in patients with a narrow QRS complex. J Am Coll Cardiol 48:2243-2250

44. Tops LF, Bax JJ, Zeppenfeld K et al (2005) Fusion of multislice computed tomography imaging with threedimensional electroanatomic mapping to guide radiofrequency catheter ablation procedures. Heart Rhythm 2:1076-1081

45. Wheatley GH 3rd, Opie SR, Maas D, Sutherland J, Diethrich EB (2007) Detection of unsuspected mitral valve prolapse using 64 multi-slice computed tomography. Ann Thorac Surg 83:1555 